\title{
Federal Toll Road Concession Program in Brazil: Is It Moving in the Right Direction?
}

\author{
Mariana Rodrigues Brochado and José Manuel Vassallo
}

\begin{abstract}
This paper assesses the toll road concession program started by the federal government of Brazil, from its beginning in 1996 until 2012. Brazil has one of the longest road networks, under private concessions, in the entire world. The authors use the case study approach, based on the available information, to analyze the evolution of the program over the course of its history. Specifically, a detailed analysis is conducted from three perspectives: those of the competitiveness of the tender, the impact of toll modifications caused by the rebalancing of the economics of the contract, and the actual evolution of the traffic flows as compared to their estimates, respectively. It is found that the most recent auctions have been very competitive. Moreover, with the original toll roads, bidders relied on early traffic forecasts that turned out to be overly optimistic, and over the years, contract rebalancing has led to large increases in toll rates. Overall, and even though Brazil's program can be considered successful in many ways, there is still considerable room for improvement.
\end{abstract}

Author keywords: Toll road; Traffic analysis; Toll fares; Case studies; Brazil; Highways and roads; Concession; Infrastructure.

\section{Introduction}

The Brazilian transportation system has around 1.0 million $\mathrm{km}$ of roads, with only $14 \%$ of them being paved. Road transport is by far the most common mode of transportation in Brazil. In 2012, the road share was $61 \%$ for freight and $42 \%$ for interurban passenger transport [Confederação Nacional do Transporte (CNT) 2012]. Road networks in Brazil are managed at different governmental levels, according to their functional roles. Networks whose main role is to connect different states (interstate networks) are owned and managed by the federal government, whereas roads that are mostly, or entirely, within a single state, are owned and managed by that state.

In the $1980 \mathrm{~s}$, there was a reduction in the pace of road investment in Brazil because of budgetary constraints. The approval of a new constitution in 1988 was a crucial step leading to the implementation of road concession programs, which appeared as a solution to increase investment. With the aim of enhancing Brazilian competitiveness and boosting economic growth by promoting market integration among different regions, the federal government launched its first interstate Road Concession Program in 1995 to upgrade, maintain, and operate five brownfield stretches of road, totaling 854.5 kilometers. The contracts were based on the rehabilitate, operate, and transfer (ROT) model. Years later, some states, including São Paulo, Rio de Janeiro, and Rio Grande de Sul, also started their own road concession programs, with different approaches.

Different public private partnership (PPP) arrangements have been implemented around the world to build/upgrade, maintain, operate, and finance new or existing roads. All these models were based on different types of agreements that can be classified in many ways. Among those ways would be to classify according to where the revenue comes from: that is, either from users, through tolls, or from budgetary resources of the government. In tollroad PPP models, usually called concessions, most revenues come from explicit tolls directly collected by private developers from users. Consequently, the pricing approach is bundled into the contract. User payments should be enough to generate sufficient cash flow for paying back the expenditures and the financial cost of the project.

By 2012, the Brazilian economy had changed from one of low and volatile growth to one of moderate and relatively stable growth because of lower interest rates that encouraged significant private and public investments. Among the beneficiaries of this growth and relative stability was the concession road system. As of 2012, in Brazil-accounting for federal, state and municipal roads there were a total of 55 road concession contracts, involving $15,381 \mathrm{~km}$ of paved roads, representing around $7 \%$ of the total paved roads in the country.

Through a review of the literature, several studies and research papers dealing with Brazilian road concessions have been identified. Rosa et al. (2010) reviewed the Brazilian concession program launched by federal and state governments. Barbo et al. (2010) explained the evolution of the regulations in road concessions and the changes implemented in the contract models at each stage of the concession program. Véron and Cellier (2010) published their research dealing with financial aspects of the road concession programs in Brazil. They conducted a comparison of costs and toll rates for each stage of the road concession program of the federal government. The Institute for Applied Economic Research in Brazil (IPEA) $(2011,2012)$ has published its calculations as to the public and private investment in roads per kilometer from 2003 to 2011, has calculated the average toll rate for each concession 
program now in existence in Brazil, and further, has proposed an investment plan for the next 15 years.

From the review of the literature, it appears that most of the studies and research on road concessions in Brazil conducted up to now have been either mostly practical in their focus or have limited their attention to this or that specific aspect of the program. The authors have not identified any published analysis that offers a thorough evaluation of the performance of the program as a whole. This is the need that this paper is intended to meet.

This paper focuses on the road concession programs launched by the federal government of Brazil from 1995 to 2012 . The authors did not analyze in detail the concession programs promoted by the individual states of Brazil because data from these programs are both scarce and, where available, hard to compare because the concession programs are not sufficiently homogeneous in their approaches. Although data from the states are rather dispersed, difficult of access, and not systematically organized, data from federal concessions are regularly and systematically published in the annual reports of the National Agency for Land Transport (ANTT).

The aim of this paper is to conduct an analysis of the performance of the concession program launched by the federal government of Brazil from three different perspectives: the outcome of the auctions, the revision of tolls, and the real traffic flows as compared with the original estimates. "Performance" is defined as the adequate fulfillment of the expected goals for society as a whole. This includes benefits for users (adequate maintenance, fluid traffic, low tolls), the government, taxpayers, private promoters, and lenders. Concessions will be considered to perform well if they ultimately meet the social goals they were designed for.

This research is original and relevant for several reasons. First, Brazil is the country with the longest toll road network under concessions in the world (Carpintero et al. 2012). Second, the authors have not found in the literature any systematic and thorough research dealing with Brazilian road concessions, how they have functioned, and how they might function better. Third, the case of Brazil should be of interest for emerging countries intending to promote extensive programs of road building using the concession method. The methodology used is based on the case study analysis (Flyvbjerg 2011), because there is not enough data available to reach conclusive results on the basis of statistical analysis.

The study is divided into three main sections. In the first one, the paper provides an overview of road concessions in Brazil. The second section sets out the main features of federal road concessions: toll setting and economic regulation, tendering and contracting, risk allocation, and financial sources and their costs. Finally, in the third section, the paper offers an assessment of the program from a threefold point of view: competitiveness in the original tender, toll modification, and traffic behavior.

\section{Road Concessions in Brazil: An Overview}

\section{Brief History}

The first toll road concession program was launched by the federal sovernment in 1995 as part of the National Privatization Program. The government aimed to increase investments and quality in roads without spending the public budget.

By 2012, the federal government had granted total concessions to the private sector amounting to $4,774 \mathrm{~km}$ of roads. The federal govermment launched concession programs in three different stages (see Table 1). In the first stage, from 1995 to 1998, six concessions were granted totaling $1,482.4 \mathrm{~km}$. These concessions now offer a track record that is sufficiently extensive to permit evaluation of
Table 1. Road Concession Program by the Federal Govermment

\begin{tabular}{lccr}
\hline Stage & Beginning of the contract & $\begin{array}{c}\text { Number of } \\
\text { concessions }\end{array}$ & $\begin{array}{c}\text { Length } \\
(\mathrm{km})\end{array}$ \\
\hline 1 & June 1995 to July 1998 & 6 & $1,482.4$ \\
2.1 & February 2008 to March 2008 & 7 & $2,600.0$ \\
2.2 & October 2009 & 1 & 680.6 \\
3.1 & September 2013 & 2 & $1,753.5$ \\
3.2 & April 2013 & 1 & 475.9 \\
3.3 & September 2013 $^{\text {a }}$ & 7 & 5.748 .3
\end{tabular}

Note: Elaborated by the authors with data taken from ANTT (2011).

"Scheduled.

their performance. The second stage, in 2008 and 2009 , involved the granting of eight concessions amounting to a total of $3,280 \mathrm{~km}$. During the third stage, which began in 2012 with what is referred to as substage 3.2 , concession awarded cover $2,229.4 \mathrm{~km}$ of roads, with the contract signed in April 2013. The bids for stage 3.1 and 3.3 are scheduled to take place on 2013 .

The concession program seems to be successful in attaining its objective: to improve maintenance and road conditions in Brazil. In $2012,86 \%$ of the roads operated by concessionaires were in "very good" or "good" condition, considering aspects of pavement, signage, and design. In contrast, only $27 \%$ of the roads managed by the government had achieved the same classification (CNT 2012).

In addition, the experience it obtained from the concession contracts awarded in the first stage enabled the government to improve the concession process by restructuring government institutions and introducing changes in the road concession model. These changes both improved the contract design and streamlined the bidding process.

\section{Legal and Institutional Framework}

For the development of the first stage of the Federal Road Concession Program, new legislation, the Concessions Law 8987/ 1995, was passed. It defined the obligations and rights of users, concessionaires, and the government, and established the bidding procedure and the pricing policy for these contracts. This law was further complemented by two later acts of legislation: Law 9074/ 1995, which laid out general rules applicable to granting concessions to private parties for supplying public services, and Law 9277/1996, which allowed local states in Brazil to set out for concessionary bids stretches of federal road within their complete jurisdiction.

According to this legislation, road infrastructure concessions are defined as the transference of the management of a defined stretch of road to a private company for a period of time contractually agreed on in advance. During the contract term, concessionaires are committed to undertaking all the work necessary to ensure adequate service to the users. The contract defines adequate service as that which meets the following conditions: regularity, continuity, efficiency, comfort, safety, fluid traffic flow, modernization, universality, courtesy toward the public, and reasonable tariffs. These conditions are monitored regularly by the government and, for some of them, there is a set of requirements imposed on the concessionaire to ensure compliance with minimum standards as to the following: cleaning and maintenance of the pavement, signage, drainage system, safety and structural elements. Concessionaires are, in turn, entitled to charge tolls to the users to finance their required activities. At the end of the period, the asset-that is, the road-will revert to the government in perfect operating, and maintenance conditions, as defined according to the contract. 
Almost 10 years after the approval of the concessions law, a new law related to infrastructure management was passed: the Public Private Partnerships (PPP) law 11079/2004. This law is applicable to any kind of infrastructure, and, unlike the concessions law, it allows for subsidies to be given to private sponsors in charge of managing public infrastructure assets. This law substantially broadened the possibility of transferring public assets to private sponsors, mainly those assets judged to be socially efficient and strategic for the country, but which were not financially feasible for private sponsors to assume responsibility for without public subsidies. It also enabled the government to implement social policies by setting up toll rates more affordable to everybody. In 2007 the states started to use this type of contract for roads. However, at the end of 2012, the federal government had not yet made use of it, basically because all the stretches of road awarded to private concessionaires by the federal government at that time were profitable by themselves and no further inducement, through subsidies, was necessary.

The public institution entrusted to manage and regulate federal road concession contracts at present is the Agência Nacional de Transportes Terrestres (ANTT), or in English, the National Agency for Land Transport. This agency was created in 2001, five years after the first federal road concession was granted. The ANTT, which is in charge of regulating the land transport sector, including federal road concession, enjoys economic independence and the power to regulate concessions within its scope of competence. Specifically, it is in charge of tendering the concessions and also of monitoring and regulating the contracts, once awarded, during the term of the concession.

The latest institutional change in the transport sector worth mentioning occurred in 2012. It was the creation of the Enterprise for Planning and Logistics (EPL). The EPL is responsible for providing planning services to the transport sector, engaging in relevant research, and obtaining environmental permits for transportation projects. This change was prompted by the general belief that the existing institutional framework was not adequate and was the cause of the lack of progress, both in the development of concessions programs and in the implementation of public-private partnerships (Véron and Cellier 2010). This new institution aims to fill a gap in the areas of policy formulation, planning, and transport research in Brazil.

\section{Main Features of Federal Road Concessions}

\section{Toll Setting and Economic Regulation of the Contract}

Tolls are charged at toll plazas, both manually (with human toll takers) and using machines that automatically record the toll. The road system is such that users going through a toll plaza are charged a fixed price irrespective of the distance they have already driven or will be driving subsequently. The low population density in Brazil makes it economically unfeasible to set up toll plazas at every access point. Toll plazas are located on the main points of the roads, but these are ordinarily located far from urban areas to minimize the traffic backup in densely populated locales. Toll rates applicable to vehicles other than cars are calculated as a multiplier of the toll rate for cars. The multiplier is equal to the number of axles used.

Toll rates are updated every year according to two different triggers: adjustment and revision. The adjustment index controls for the effect of inflation. The revision index affects directly the basic toll rate (BR), and it is applied to compensate the concessionaire for risks that were not allocated to it in the contract, such as, for example, additional works that the government may subsequently require.

The adjustment index used for the federal concessions belonging to the first stage, contracts in the period from 1995 to 1998, was based on the weighted average of a basket of prices, replicating the main cost components for road works. The concession contracts belonging to the second stage, from the period 2008 to 2009 , used a specific inflation rate, the consumer price index (CPI), which is known in Brazil as IPCA. In the third stage, from 2012 on, the contracts adopted the price cap regulation to incentivize efficiency and to share productivity gains made by the concessionaires with the users. The adjustment index is set on the basis of CPI-X, which uses the CPI less the efficiency factor, called the X-factor. The $\mathrm{X}$-factor is zero at the beginning of the contract and increases $0.25 \%$ at the end of every five-year period.

Unlike the adjustment, the revision is a means to compensate the concessionaire for those risks that are not borne by them according to the contract terms. These risks are not set at the discretion of the ANTT. They include, for example, force majeure risks, such as natural disasters, modification of direct taxes, or work delays cansed by problems in the public sector. These all constitute risks that the concessionaire should not be responsible for, as they are not a foreseeable and nomnal part of the business. The current practice is that contracts are to be revised on an annual basis. However, to reduce the frequency of the revisions, the ANTT passed a provision whereby contracts will be completely revised every five years.

In addition, from 2009 on, there was an important change in the way that the economics of the contracts were to be rebalanced in cases where new works were added by the government to the concessionaire's responsibilities. As the contract stipulates that the risk of additional works added by the government is not borne by the concessionaire, these additional works will result in toll rate revision. Before 2009, the costs of these new works were included in the cash flow of the original financial model by adopting the economic and financial conditions at the time of bidding. Therefore, this situation could derive an extra profit or loss to the concessionaire if the conditions at the time of the revision were better or worse than at the time the financial model was produced. To minimize this when new works are asked of the concessionaires by the government, after 2009 the government began to use a corrected (marginal) cash flow for the new works to rebalance the contract. This cash flow considers the economic scenario at the time of the revision using the real traffic flow to calculate the incomes, the market prices to estimate costs, the rate of retum based on the long-term interest rate (TJL) of the Development Bank of Brazil (BNDES), and the inflation rate. This modification aims to remunerate the concessionaire for the actual cost to the concessionaire of the additional work, irrespective of the original conditions, as it is a new work added after the tender. For the third stage, from 2012 , the innovation in the contract was that the corrected cash flow now uses an internal rate of return based on the weighted average cost of capital (WACC).

\section{Tendering and Contracting}

Toll road concessions in Brazil are granted through a competitive tender process. Concession terms are fixed and defined in the contracts, and in most of the cases they last for 25 years. The tender procedure followed during the first stage, in the period from 1995 to 1998 , has undergone some change in the subsequent stages. For the concessions granted in the first stage, the tender consisted of three phases: first, an open prequalification; second, a definition of the characteristics of the project conducted by the government along with the prequalified bidders; and third, a final auction on the 
toll rates. The bidder offering the lowest toll will end up winning the tender. In the first stage of the federal concession program, only engineering and construction companies were allowed to present offers, whereas financial institutions were not allowed to submit bids.

The tender process used in the second and third stages, from 2008 on, changed because legislation as to such tenders, for road concessions in Brazil, has been modified. Important changes were introduced. Before launching the tender, the government was now required to present a basic project, so the second phase of the tender-the defining of the characteristics of the project-was eliminated. Instead of that, the legislation introduced a new requirement: a series of public hearings about the technical and economic studies of the concession project even before beginning the auction.

In addition to the elimination of the second phase of the tender, the first and third phases of the tender were, in essence, now reversed. From 2008 on, in the first phase the most competitive offer will be quickly identified. Once this offer has been so identified, the following phase of the tender will be devoted to checking whether the qualifying documents of the best bidder are all in order. If the best offer qualifies in this phase, it will be awarded the contract. If it does not, the government will continue the process with the second-best offer from the first phase of the tender. These changes resulted in faster auctions because they avoided the need for the government to evaluate the qualification documents of all the offers. Another change introduced in the second and third stages, compared with the first one, was to permit the participation of many other types of bidders, including financial institutions, pension funds, and investment funds, within the bidding consortia.

\section{Risk Allocation}

A study conducted by Ke et al. (2010) in four countries revealed that risks related to construction, design, finance, and operation are usually allocated to the private sector, whereas political risks are usually allocated to the public sector. The toll road concession approach implemented in Brazil transfers most of the key risks onto the private sponsors. Concessionaires bear traffic, finance, construction, maintenance, and operation risks. Expropriation risk is not that important because most of the concessions are brownfield projects.

Traffic risk, which is hardly manageable by any stakeholder, is borme completely by private concessionaries. This means that private sponsors will end up collecting windfall profits if traffic turns out to be higher than expected, but they might end up incurring large losses if traffic is lower than expected. Unlike other Latin American countries such as Chile and Colombia, Brazil has never implemented traffic risk mitigation guarantees (Vassallo and Izquierdo 2010). In this respect, different case studies show different results. Vassallo (2006) found that mitigating traffic risk in Chile was very effective. However, Heravi and Hajihosseini (2012) report unsuccessful experiences with little or no demand risk on the private party, from a study of two toll road projects in Iran.

Financial risks are also allocated to private sponsors in Brazil. Interest rates that are lower than expected will bring about sizeable windfall benefits to concessionaires, which will not be transferred to the users. This situation actually occurred in Brazil, where interest rates decreased dramatically over the years, so the refinancing of the initial loans was quite favorable for the sponsors.

The allocation of construction risk has evolved over time. The total cost of work may be calculated as quantity units $x$ unit cost. This information is included in the financial proposal of the bidder. Despite what the bidding is for the lower toll rate, after the tender procedure all the documents submitted by the winning bidder become part of the contract, and they can be used to revise the toll rate during the concession period. Originally, the risk related to the price of materials- - unit cost risk-was allocated to concessionaires, whereas the risk of the amount of material used-quantity risk - was transferred to the users through the periodic revision of tolls. Consequently, a sharp variation in the price of a certain unit of work, such as material or labor force, which has to be borne by the concessionaire while using additional work units, that use amount of material or labor force different from the amounts calculated in the initial bid, will however ultimately be paid by users through higher revised tolls. This approach was shown not to be efficient, because concessionaires did not have an incentive to employ fewer resources and, as a consequence of that, the approach was modified in the second and third stages.

The changes introduced in the second and third stages related to the approach for the allocation of construction risk were aimed at reducing the frequency of contract revisions and at incentivizing concessionaires to increase their productivity. From the second stage on, concessionaires had to bear the bulk of the construction risk, both as to quantity and unit cost. In addition, contracts entered into during the second and third stages distinguished between mandatory and conditional works. Mandatory works have to be undertaken by the concessionaire following a predefined schedule; for example, third lanes should be built during the fifth year of the concession period. Conditional works, however, have to be built by the concessionaire only if certain performance targets set up in the contract are eventually reached. Consequently, conditional works do not have a fixed date when they must be constructed. For instance, the concessionaire may be required to build an additional lane only when traffic flows reach a certain volume, as determined by the terms of the contract. The concessionaire cannot be certain, nor can the government, when that traffic volume will be reached, if it ever is.

Since 2008, maintenance and operation performance targets have been added to concession contracts belonging to the second and third stages. The performance targets selected for such inclusion refer to pavement, road signage, maintenance, and cleaning of the road. From stage 2.2 onwards, a toll rate discount was triggered if and when certain performance levels set out in the contract were not achieved. This discount is applicable to the toll rate if the service provided by the concessionaire to the user is below the service standards agreed on in the contract.

\section{Financlal Sources and Their Costs}

In 1995, at the beginning of the first stage of the federal toll road concession program, Brazil was experiencing high inflation and high interest rates. Project internal rates of retum (IRRs) required by private sponsors hardly ever fell below $18 \%$ per year. The financial costs were consequently very high. In 2012, Brazil still ranked among the countries with the highest nominal and real interest rates in the world. However, from 1995 to 2009 , there was a gradual reduction in both nominal and real rates. The interest rate in Brazil that most influences monetary policy, an ovemight rate called Selic, was around $25 \%$ per year in the late 1990 s. However, only 10 years later, it had fallen to around $10 \%$ per year. Since 2005 , this scenario has created positive expectations among economic actors, encouraging a new cycle of private investments directed at the modernization and expansion of production capacity. The decrease in the interest rate has caused a substantial reduction in the financial costs of such projects. The IRR of the projects awarded from 2008 to 2012 was around $8.5 \%$ per year, much lower than it was at the first stage. 
According to Lacerda (2005), the sources of money to fund the initial works of a toll road project in Brazil are, on average, distributed as follows: $25 \%$ equity provided by the sponsors, $58 \%$ loans, and $17 \%$ cash generated by toll charges. The initial works include the rehabilitation of the road during the first five years of the concession period. As they are brownfield projects, concessionaires can start charging toll rates after initial maintenance work and the construction of toll plazas, which usually take six months. From the distribution of sources, financial costs of requiring equity and debt are hence relevant for the project. Ultimately, loans and contributions from sponsors will be repaid by users from toll sources.

Because of the high interest rates in Brazil, concessionaires relied very much on loans provided by the State Bank for Economic and Social Development (BNDES). This government-owned bank played a key role in the long-term financing of concession projects. In contrast, private banks charged high interest rates and did not feel comfortable providing long-term loans in the unstable scenario that characterized Brazil's economy at the beginning of the first concession stage.

For this reason, BNDES has been the main source of funding for investment in road concessions in Brazil, by reducing the financial costs of the projects through longer terms and subsidized rates. In 2010 , BNDES supplied $64 \%$ of the total credit extended in the short- and medium-term and $100 \%$ of the long-term credit (Brochado and Vassallo 2012). Its liabilities come mostly from money allocated from the federal budget, or from the funds accumulated by the unemployment insurance system.

The BNDES credit line for the road sector has the following main characteristics (BNDES 2011):

- It offers 10-year loans with long grace periods-the period of time that the lender allows the borrower to start paying back the principal of the loan $\longrightarrow$ of up to 5 years;

- It can finance up to $60 \%$ of the total capital cost;

- It offers lower interest rates, based on the long-term interest rate (TJLP), which in 2012 was at $5 \%$ per year, whereras private banks use the interbank deposit certificate (CDI), which stood at $8.4 \%$ in 2012 ;

- It offers loans which are denominated in the Brazilian currency, the same currency, that is, in which the tolls are paid and toll revenues calculated.

Such a financing framework proved adequate to support the toll road concession program at its origins because of the tough financing conditions offered by the market at that time. According to Verron and Cellier (2010), with the expansion of the Brazilian capital markets and the more favorable financing conditions, the picture changed, and emerging concessionaire groups increasingly refinanced early loans, as well as subsequent acquisitions, on the basis of debentures.

\section{Assessment of the Performance of the Federal Concession Program}

This section evaluates the performance of the federal road concession program using the data available as of 2012. This analysis focuses on three key aspects: the competition among bidders at the tender phase; the changes in the yearly toll calculation; and the changes in the amount of actual traffic, as compared with the forecasts at the time of the bidding. The analysis of all these aspects, along with the previous description of the program, provides enough information to obtain interesting results about the performance of road concessions in Brazil. The data used were collected from the annual reports of the National Agency for Land Transport (ANTT).

\section{Competitiveness in the Tender}

The main objective of tendering in contracts for public infrastructure with characteristics typical of natural monopolies is to promote competition among private operators for the right to construct and manage the infrastructure for a certain period of time. The tender will be more effective insofar as it is able to promote greater competition and consequently result ultimately in lower tolls for the users. In this respect, a higher tariff discount would presumably mean a more effective tendering process.

For the case study of the Federal Toll Road Concession Program, the authors analyzed the effect that the competitiveness in the tender-measured by examining the number of bidders per tender - has on the toll rate discount offered by the ultimate winning bidder. The maximum toll rate (MTR) is estimated by the government in the feasibility study of the project by using their own predictions regarding the costs of the works and traffic projections. At the time of bidding, the government makes available to the bidders the feasibility study used to calculate the MTR. From this information, each bidder can calculate its own cash flow, considering its cost, traffic forecasts, and internal rates of returns. Therefore, the bidders have autonomy to construct their own cash flows on the bassis of their own forecasts and works costs predictions. The level of discounts measures the efficiency that bidders expect to reach compared with the government benchmark.

The last nine concessions awarded from 2007 to 2012 were considered, which belong to stages 2 and 3. Unfortunately, there are no data available from stage 1 . To that end, by using data available in Bolsa de Valores de São Paulo (BOVESPA) (2012), which is the stock exchange where the auction took place, the toll rate discount ultimately offered by the winting bidder is calculated according to Eq. (1). This ratio appears to be a good proxy for measuring the level of competiveness in the tender:

$$
D=100 \frac{\mathrm{MTR}-\mathrm{WTR}}{\mathrm{MTR}}
$$

where $D=$ toll rate discount in the tender (\%); MTR = maximum toll rate established by the government $(\mathrm{R} \$)$; and $\mathrm{WTR}=$ toll rate offered by the winning bidder (R\$).

The results of stages $2.1,2.2$, and 3.2 are displayed in Table 2 . There were seven auctions within stage 2.1 . They were attended by 29 groups, including domestic and foreign investors, with an average of 10 bidders per project. The auctions in this stage were extremely successful, reaching toll rate discounts of up to $65 \%$ of the maximum toll rate set up by the government. The next auction corresponded to stage 2.2. It took place in January 2009, a few months after the world financial crisis exploded. This fact prompted a substantial reduction of bidders, down to just two, even though the winner's toll rate also reflected a significant discount of $21 \%$. The most recent auction was held in January 2012, after the economic recovery. There were eight bidders, and the winner's toll rate had a discount of $45 \%$.

There is almost a perfect correlation between the number of bidders that ultimately attended the tender and the final discount achieved. Of course, the tolls offered by the winning bidder will depend on its traffic estimates, and the literature demonstrates that fierce competition in the tender encourages bidders to inflate their traffic forecasts (Baeza and Vassallo 2012). That, of course, might end up making renegotiations over the life of the contract more likely.

This fact seems to show that the larger the number of bidders in the tender the greater the efficiency obtained for the users, at least at the beginning, through the lower toll levels that result from such 
Table 2. Results of the Auctions

\begin{tabular}{|c|c|c|c|c|c|}
\hline Concessionaire & Length $(\mathrm{km})$ & Auction date & Number of bidders & Toll rate $(\mathrm{R} \$ / 100 \mathrm{~km})$ & Discount (\%) \\
\hline \multicolumn{6}{|l|}{ Stage 2.1} \\
\hline Autopista Fernão Dias & 562.1 & $09 / 10 / 07$ & 15 & $1.56^{\mathrm{a}}$ & 65.42 \\
\hline Autopista Fluminense & 320.1 & $09 / 10 / 07$ & 8 & $3.90^{\mathrm{a}}$ & 40.95 \\
\hline Autopista Litoral Sul & 382.3 & $09 / 10 / 07$ & 17 & $1.43^{\mathrm{a}}$ & 62.67 \\
\hline Autopista Planalto Sul & 412.7 & $09 / 10 / 07$ & 10 & $3.27^{\mathrm{a}}$ & 39.35 \\
\hline Autopista Régis Bittencourt & 401.6 & $09 / 10 / 07$ & 13 & $2.24^{a}$ & 49.19 \\
\hline Rodovia do Aço & 200.4 & $09 / 10 / 07$ & 3 & $4.79^{a}$ & 27.17 \\
\hline Transbrasiliana & 321.6 & $09 / 10 / 07$ & 10 & $3.23^{a}$ & 39.99 \\
\hline \multicolumn{6}{|l|}{ Stage 2.2} \\
\hline Rodobahia & 680.6 & $01 / 21 / 09$ & 2 & $1.99^{\mathrm{b}}$ & 21.00 \\
\hline \multicolumn{6}{|l|}{ Stage 3.2} \\
\hline BR-101 ES/BA & 475.9 & $01 / 18 / 12$ & 8 & $3.39^{c}$ & 45.63 \\
\hline Mean & $\longrightarrow$ & - & 9.56 & $=$ & 43.49 \\
\hline Standard deviation & - & - & 5.03 & - & 14.55 \\
\hline
\end{tabular}

Note: Elaborated by the authors with data taken from Bovespa (2012); database: Federal road concessions from 2007.

aDatabase: July 2007, exchange rate: RS1.88/US\$.

${ }^{b}$ Database: December 2005, exchange rate: R\$2.29/US\$.

${ }^{c}$ Database: January 2009, exchange rate: R $\$ 2.31 /$ US $\$$.

competition. This result is consistent with the findings obtained by Guasch (2004).

The procurement process used in Brazil, as in many other countries such as Spain, Chile, and Colombia, has been done largely on the basis of the so-called "open procedure." This is probably the most important reason why the number of bidders participating in the tendering processes for highway concessions in these countries is often quite large, which enhances competition and, consequently, low toll rates at the beginning of the contract. This procedure means that any company that fulfills the minimum requirements, as set out by the government in the contract's provisions, is allowed to participate in the tendering process. Unlike other long-term infrastructure contracts in the world (e.g., the Design Build Finance Operate contracts in the United Kingdom, and most of the PPP contracts in Germany), concession contracts in Brazil were not agreed on in negotiations between the government and the bidders, but they are based on standard contracts that are slightly modified for each specific concession. As unforeseeable events may occur during the concession period that are not included in the original contract, these contracts can be characterized as incomplete contracts, as stated by Hart (2003). However, as a result of the simplicity of the process, transaction costs for both bidders and the government are very low as compared with other countries (Sánchez Soliño and Gago 2010). So, despite the contracts being incomplete, they seem to be attractive to both the private and the public sector.

\section{Toll Evolution}

As road concessions are long-term contracts, one of the key aspects for guaranteeing users' welfare is to set affordable tolls over the life of the contract. In most concessions, mechanisms are set up for yearly toll update. Concessions will perform better for the users insofar as tolls are updated according to the purchasing power of the society. High toll rises will not be good for users, and this may tend to prove that the risk allocation approach set up in the contract was inadequate. The evolution of tolls will also enable the stakeholders to assess the quality of the contract and the regulatory system. For instance, excessive renegotiations can reduce the social gains achieved in the competitive tender.

Toll rates are regulated in different ways across different countries. In some countries, such as Japan, tolls are regularly updated by the government to repay the debt issued by a state-owned agency in charge of collecting the tolls. In many countries, such as Spain, Chile, and Italy, tolls are updated according to the contract terms on the basis of indicators linked to the CPI with slight variations. In Spain, tolls are also updated based on productivity measured by comparing the actual traffic with the previously estimated traffic. In Chile, tolls are updated based on the fulfillment of certain safety indicators. In Brazil, toll setting includes provision for both an adjustment to inflation and a revision to compensate the concessionaire for risks that the contract does not allocate to it.

Both types of toll rate updates used in Brazil (revision and adjustment) directly affect the toll rate ultimately charged to the users. IPEA (2012) conducted a study comparing the evolution of tolls charged with the inflation from 1996 to 2011 to analyze the users' perception of toll rate increases. They found that toll rates from first stage concessions increased in real terms by $121 \%$. This data provides evidence that concessionaires were likely favored by this approach, and also indicates that the adjustment and/or revision method could be not adequate.

For this reason, to evaluate the methods used to regularly update toll rates over the years in Brazilian concessions, it is necessary to analyze the evolution of tolls, making a distinction between the two components: revision and adjustment. This analysis was conducted for the toll concessions awarded during the first stage only, because the concessions concluded in the two later stages are very recent and have not as yet generated enough available data to be useful.

First, the annual toll rate growth caused by revision in year $i$ was calculated [Eq. (2)]. Revisions are the mechanism for rebalancing the economics of the concession because of risks that were not allocated to the concessionaire's side:

$$
\mathrm{ARGR}_{i}=100\left(\frac{\mathrm{BR}_{i}-\mathrm{BR}_{i-1}}{\mathrm{BR}_{i-1}}\right)
$$

where $\mathrm{ARGR}_{i}=$ annual toll rate growth caused by revision in year $i(\%)$; and $\mathrm{BR}_{i}=$ basic toll rate (not adjusted to reflect inflationary effects) concerning revision in year $i(\mathbf{R} \$)$.

If $\mathrm{ARGR}_{i}$ tums out to be a positive number, it means that there was a revision that resulted in an increase in the basic toll rates. On the other hand, if $\mathrm{ARGR}_{i}$ turns out to be negative, this means that the basic toll rate would be reduced after the revision. The data are available from 1996 , when the first concession contracts were awarded, until 2011. 
Table 3. Toll Rate Growth due to Revision

\begin{tabular}{|c|c|c|c|c|c|c|c|c|c|c|c|c|c|c|c|c|}
\hline Concessionaire & 97 & 98 & 99 & 00 & 01 & 02 & 03 & 04 & 05 & 06 & 07 & 08 & 09 & 10 & 11 & Accumulated \\
\hline Nova Dutra (\%) & 10 & 0 & -4 & 4. & I & -3 & 2 & $\boldsymbol{0}$ & 4 & $\phi$ & 2 & -1 & 1 & 1 & 0 & 14 \\
\hline Ponte Rio-Niterói (\%) & 6 & 0 & -4 & 5 & 10 & $\omega$ & 4 & I & -1 & 0 & 2 & 0 & 2 & 4 & 3 & 40 \\
\hline CONCER $(\%)$ & 15 & 0 & -5 & 7 & 6 & 5 & \pm & -1 & -1 & -4 & 0 & -1 & 2 & -2 & 1 & 26 \\
\hline CRT (\%) & 4 & 0 & -11 & tb & $\underline{z}$ & -11 & 2 & -4 & 1 & 5 & 2 & 1 & $1 \%$ & 3 & 12 & 40 \\
\hline Concepa (\%) & - & 11 & -3 & 9 & -7 & 3 & 11 & -1 & 4 & 1 & 2 & -1 & 7 & 3 & 3 & 45 \\
\hline Ecosul $(\%)$ & - & - & - & - & 一 & 8 & 8 & 8 & 8 & 9 & 8 & 0 & 0 & 5 & 3 & 73 \\
\hline Mean $(\%)$ & 9 & 2 & -6 & 8 & 2 & 0 & 6 & 0 & 2 & 2 & 3 & 0 & 5 & 2 & 4 & 39 \\
\hline Standard deviation (\%) & 5 & 5 & 3 & 6 & 6 & 7 & 4 & 4 & 3 & 4 & 3 & 1 & 6 & 2 & 4 & 20 \\
\hline
\end{tabular}

Note: Flaborated by the authors with data taken from ANTT - Annual Reports. Data base: Federal road concessions from 1996 to 2011.

The results are displayed in Table 3. On average, tolls increased by almost $40 \%$ in real terms from the beginning of the concession until 2011 . The greatest increase, that of $73 \%$ by Ecosul, probably can be explained by the unusual history of this particular concession. It is a federal road granted by Rio Grande do Sul State that faced political problems in the early years. As a result, it was returned to the control of the federal government, leading to revisions in the contract to adapt to the federal program.

These values do not incorporate inflationary adjustments over the life of the concession contracts. One of the causes of revision in the first stage is precisely the fact that the part of the construction risk related to quantity was not allocated to the concessionaire. The values of $\mathrm{ARGR}_{i}$ vary across different concession projects, even though three of them are close to the average value.

This fact demonstrates that there were many events that justified the rebalancing of the economics of the contract to compensate the concessionaire for risks or actions of the government that were not allocated to them, or possibly not even mentioned, in the original contract. This can be a consequence of the incompleteness of contracts when the "open procedure" is used to tender concessions. The basic toll rate changed in $85 \%$ of the years analyzed. In addition, most of these changes reflected toll rate increases rather than reductions. This result is consistent with the research conducted by Guasch (2004) that found that $62 \%$ of the renegotiation processes ended up with increases in toll rates.

Table 3 shows how from 2003 onwards the revisions appeared to be more moderate. The main reason for this is that in 2002 the National Agency for Land Transport was created to regulate and provide oversight for road concessions more effectively. The independence of this regulatory agency likely contributed to reducing the need to revise toll rates as often, or in as great an amount, as previously.

The other component of the toll rate modifications, over time, is the adjustment mechanism, which compensates for inflationary losses. For the concessions dating back to the first stage - the ones with a long track record as of 2012 -the yearly adjustment was calculated on the basis of a basket of prices that included the labor costs and materials for the construction industry. This calculation resulted in inflationary adjustments that were much higher than the growth in average consumer prices.

Table 4 compares the toll rate increase attributable to the approach of periodic adjustments with Brazil's most popular consumer price index (IPCA) for the same period. The values in Table 4 do not include the effect of toll rate revision previously explained. This table shows how such yearly adjustments were far above the rise in consumer price indexes. The result was that the tolls charged by the concessions became progressively more onerous for users. It is precisely this that ultimately led the government to change the adjustment approach in the concession contracts granted after 2008 towards an adjustment index based only on the inflation rate (IPCA).

\section{Traffic Behavior}

Traffic is a key driver for the toll concession business. Comparing ex ante and ex post traffic permits the evaluation of whether the project is ultimately viable for the concessionaire. Thus, forecasting traffic correctly turns out to be crucial in concession contracts where traffic risk is to be borne by the concessionaire, and the revenue of the project comes only from toll revenues.

As the winner of the bid is the one who offers the lowest toll rate, bidders are often tempted to overestimate the traffic, expecting that their losses will be offset by future renegotiations of the contract (Guasch 2004). The literature shows that bidders tend to act strategically in competitive auctions to win the competition at all costs (Bain 2009; Baeza and Vassallo 2010). Baeza and Vassallo (2012) reported significant bias towards traffic overestimation, with $50 \%$ of the deviation during the ramp-up period in road concession contracts in Spain linked to the availability of frequent renegotiations.

This section explores how real traffic behaves in the concessions of the federal program of Brazil, using a specific record of traffic, to identify whether there has been overestimation of traffic by bidders. The only data that are available from 2002 to 2011 are analyzed.

The traffic behavior analysis attempts to evaluate the adequacy of the road concession program by comparing the real level of traffic compared with the original forecasts. To evaluate the traffic forecast accuracy, there are two defined indicators. The first one is the annual traffic inaccuracy $\left(\mathrm{ATI}_{i}\right)$, which evaluates the inaccuracy of traffic forecast, comparing the real traffic with forecast values for each year, using Eq. (3):

Table 4. Difference between the Toll Rate Growth due to Inflationary Adjustments and Inflation (IPCA)

\begin{tabular}{lcccc}
\hline & Beginning of & $\begin{array}{c}\text { Inflationary } \\
\text { adjustments } \\
\text { accumulated } \\
\text { Concessionaire }\end{array}$ & $\begin{array}{c}\text { Inflation } \\
\text { growth } \\
\text { (IPCA) } \\
(\%)\end{array}$ & $\begin{array}{c}\text { Difference } \\
(\%)\end{array}$ \\
\hline Nova Dutra & August 1996 & 228 & 154 & 74 \\
Ponte & August 1996 & 249 & 154 & 95 \\
Rio-Niterói & & & & \\
CONCER & August 1996 & 210 & 154 & 56 \\
CRT & September 1996 & 213 & 153 & 60 \\
Concepa & October 1997 & 249 & 139 & 110 \\
Ecosul & March 2001 & 117 & 100 & 17 \\
\hline
\end{tabular}

Note: Elaborated by the authors with data taken from ANTT-Annual Reports and IBGE (2012); database: Federal road concessions from 1996 to 2011. 
Table 5. Annual Traffic Inaccuracy of Traffic Forecasts $\left(\mathrm{ATT}_{i}\right)$

\begin{tabular}{|c|c|c|c|c|c|c|c|c|c|c|c|c|}
\hline Concessionaire & 2002 & 2003 & 2004 & 2005 & 2006 & 2007 & 2008 & 2009 & 2010 & 2011 & Mean & $\begin{array}{l}\text { Standard } \\
\text { deviation }\end{array}$ \\
\hline Nova Dutra (\%) & -4 & -8 & -4 & -8 & -10 & -9 & -2 & -5 & -2 & 4 & -5 & 4 \\
\hline Ponte Rio-Niterói (\%) & -6 & -10 & -14 & -15 & -17 & -24 & -15 & -15 & -15 & -13 & -14 & 5 \\
\hline CONCER $(\%)$ & -22 & -27 & -28 & -28 & -29 & -23 & -21 & -15 & -14 & 0 & -21 & 9 \\
\hline CRT $(\%)$ & . -8 & -11 & -7 & -11 & -11 & -12 & -2 & -16 & 11 & 1 & -7 & 8 \\
\hline Concepa $(\%)$ & -32 & -34 & -33 & -36 & -36 & -34 & -31 & -32 & -32 & -29 & -33 & 2 \\
\hline Ecosul $(\%)$ & -14 & -14 & -11 & -21 & -19 & -8 & -5 & $\rightarrow$ & 2 & 12 & -8 & 10 \\
\hline Mean (\%) & -14 & -17 & -16 & -20 & -20 & -18 & -13 & -15 & $-\mathrm{Ai}$ & -1 & - & - \\
\hline Standard deviation il. & 11 & 11 & 12 & 11 & 10 & 10 & 12 & 10 & 15 & 15 & - & - \\
\hline
\end{tabular}

Note: Elaborated by the authors with data taken from ANTT-Annual Reports; database: Equivalent traffic of federal road concessions from 2002 to 2011.

$$
\mathrm{ATI}_{i}=100 \frac{\mathrm{ET}_{i}^{R}-\mathrm{ET}_{i}^{F}}{\mathrm{ET}_{i}^{F}}
$$

where $\mathrm{ATI}_{i}=$ annual traffic inaccuracy in year $i(\%) ; \mathrm{ET}_{i}^{R}=$ equivalent traffic (real) in year $i$ (vehicles); and $\mathrm{ET}_{i}^{F}=$ equivalent traffic (forecasted) in year $i$ (vehicles).

For analyzing traffic evolution the "total equivalent traffic" of the year was used, which is obtained by multiplying the number of vehicles using the concession road being analyzed by their respective toll rate multipliers. This is equal to the number of vehicles' axles. This variable is used because it is directly related to the concessionaire's income, once the traffic is multiplied by the toll rate multiplier for each vehicle. Real values are the ones actually observed, whereas forecasted values are the ones presented by the winning bidder in his offer.

If $\mathrm{ATI}_{i}$ is negative, this means that real traffic was ultimately lower than expected, so traffic was overestimated. If $\mathrm{ATI}_{i}$ is positive, this means that traffic was underestimated.

Table 5 shows the values of $\mathrm{ATT}_{i}$ for road concessions in Brazil. For the period under analysis, all concessionaires overestimated traffic in almost every year. In some cases, the forecasts exceeded the real traffic by $30 \%$. Only Nova Dutra presents a misestimate that fell within $5 \%$ of the real figure for all years. This concession is for the road link between São Paulo and Rio de Janeiro, the two largest cities in Brazil, so it already had a consolidated traffic flow when the concession was started. The rest of the concessions examined exhibit inaccuracies in a range between $-7 \%$ and $-33 \%$ compared with the original proposal. The better results of the most recent years may be a consequence of Brazilian economic growth, which was reflected in a substantial traffic flow increase that would likely be closer to, or not as different from, the original estimates of traffic on which successful bidders for concessions initially relied.

The second indicator used in this analysis measures the annual traffic growth $\left(\mathrm{TG}_{i}\right)$. This indicator gives the forecast and the real traffic growth for each year using Eq. (4):

$$
\mathrm{TG}_{i}=100 \frac{\left(\mathrm{ET}_{i}-\mathrm{ET}_{i-1}\right)}{\mathrm{ET}_{i-1}}
$$

where $\mathrm{TG}_{i}=$ traffic growth in year $i(\%)$; and $\mathrm{ET}_{i}=$ equivalent traffic (either forecasted or real) in year $i$ (vehicles).

Table 6 shows the values of traffic growth $\mathrm{TG}_{i}$ for the six concessions of the first stage. Almost half of the data analyzed show a difference on forecast and real growth above $5 \%$. Table 6 shows the

\begin{tabular}{|c|c|c|c|c|c|c|c|c|c|}
\hline Concessionaire & 2003 & 2004 & 2005 & 2006 & 2007 & 2008 & 2009 & 2010 & 2011 \\
\hline \multicolumn{10}{|l|}{ Nova Duira } \\
\hline Forecast (\%) & 3 & 3 & 33 & 48 & 4 & -2 & 3 & 20 & 3 \\
\hline Real $(\%)$ & -1 & 9 & 39 & 45 & 4 & 5 & -1 & 24 & 9 \\
\hline \multicolumn{10}{|l|}{ Ponte Rio-Niterói } \\
\hline Forecast $(\%)$ & 3 & 6 & -1 & 2 & 11 & -7 & 2 & 1 & 1 \\
\hline Real $(\%)$ & -1 & 1 & 0 & -1 & 3 & 4 & 1 & 2 & 3 \\
\hline \multicolumn{10}{|l|}{ CONCER } \\
\hline Forecast (\%) & 4 & 4 & -3 & 1 & 2 & 2 & 2 & 1 & 1 \\
\hline Real $(\%)$ & -3 & 3 & -3 & -1 & 11 & 5 & 9 & 3 & 17 \\
\hline \multicolumn{10}{|l|}{ CRT } \\
\hline Forecast $(\%)$ & 4 & 4 & -4 & 2 & 5 & 0 & 11 & -24 & 16 \\
\hline Real (\%) & 2 & 8 & 0 & 2 & 2 & 12 & -5 & 0 & 6 \\
\hline \multicolumn{10}{|l|}{ Concepa } \\
\hline Forecast (\%) & 4 & 4 & -4 & 4 & 3 & 4 & 3 & 11 & 4 \\
\hline Real $(\%)$ & 0 & 6 & 1 & 5 & 7 & 9 & 1 & 12 & 8 \\
\hline \multicolumn{10}{|l|}{ Ecosul } \\
\hline Forecast (\%) & 7 & 2 & -4 & 1 & 2 & 0 & 2 & 3 & 2 \\
\hline Real (\%) & 7 & 6 & 8 & 4 & 17 & 3 & 2 & 11 & 12 \\
\hline Brazilian GDP (\%) & 1.1 & 5.7 & 3.2 & 4 & 6.1 & 5.1 & -0.3 & 7.5 & 2.7 \\
\hline
\end{tabular}

Table 6. Forecast and Real Traffic Growth $\left(\mathrm{TG}_{i}\right)$ and Brazilian GDP Growth

Note: Elaborated by the authors with data taken from ANTT-Annual Reports and IBGE (2012); database: Equivalent traffic of federal road concessions from 2002 to 2011. 
evolution of the real GDP growth as well, to analyze the impact of economic growth on traffic growth inaccuracy.

Table 6 reveals that years with high GDP growths coincide with high real traffic growth, whereas years with low or even negative growth in GDP coincide with low real traffic growth rates. Moreover, the growth in traffic seems to be higher than GDP growth; the elasticity of road demand (traffic) as compared with economic growth seems to be higher than 1 . This result confirms the importance of economic growth on the increase in traffic demand, particularly when toll roads do not have a clear alternative competing with them.

The comparison of these results with previous studies conducted in Spain (Baeza and Vassallo 2012) and with a worldwide database (Bain 2009) indicated similarities in traffic level overestimation, mainly in the early years of operation. In addition, estimates accuracy in Brazil also improved over time - reducing $\mathrm{ATI}_{i}$ value-but deviation increased. However, Brazil presents lower values of inaccuracy, probably because concessions are brownfield projects and there are no competitive free roads.

\section{Conclusions}

In this paper the performance of the federal toll road concession program that has been implemented in Brazil was assessed by evaluating the outcome of the auctions, the toll update system, and the evolution of real traffic compared with the forecasts.

Overall, it was found that the federal toll road program implemented in Brazil was effective in two ways: first, in terms of the large number of kilometers of roads that were rehabilitated and upgraded; second, in the benefits that accrued to the users of the roads from the noticeable improvement of the maintenance and operation of the roads. In addition, the initial public opposition against tolls decreased over the years as users became aware of the many advantages of having good roads.

Moreover, the government has been making an effort to improve the program over the years through the construction of a better institutional framework, the offering of more sophisticated contracts, the use of a better risk allocation approach, and the implementation of a new tender procedure to achieve faster and more competitive auctions. Private sponsors in turn have proven able to comply with their obligations to the lenders. In spite of this progress, the authors consider that there is still a long way to go to improve the quality of contracts, and the analysis conducted indicates some key challenges for the system of road concessions in Brazil in the future.

Regarding the tender process, there is a lot of concern about the low toll rates obtained in the recent auctions, despite its apparent advantage for users. In this respect, it was found that because of the tender process-basically an auction that awards the concession to the bidder who offers to do the work asked and is willing to rely on the lowest toll-concessionaires tend to submit aggressive offers characterized by low tolls, which are often supported by overestimates in their traffic forecasts. This would be good for users if tolls remained stable over the years. However, this has not been the case, because toll revisions in the end lead to higher toll levels. Huge toll rate increases, of course, are not desirable because they can eliminate the gains of a competitive bid and the road-using public suffers.

Another peculiar aspect of road concessions in Brazil is that most of the debt comes from a public bank, the BNDES, which provides subsidized loans to concessions. This institution contributed a lot to reducing the financial cost of concessions projects in Brazil when interest rates were extremely high. However, the fact that this is a state-owned bank means that, in the final analysis, the government is indirectly bearing part of the risks of the concession contracts. This approach is thus worrisome for the government because if a severe recession eventually arrives, the BNDES will be bearing an important risk.

To avoid these problems, it would be advisable that the government of Brazil attempt to make the future concessions more attractive for private investors, particularly such long-term institutional investors as pension funds or insurance companies. To do so, the government should make an effort to draw up much more detailed contracts to reduce continuous revisions, which ultimately result in toll rate increases. In addition, the government should improve the risk allocation approach that mitigates some risks, such as traffic risk, which are barely manageable by the private sector, using, for example, flexible-term contracts.

Agência Nacional de Transportes Terrestres (ANTT). (2011). "Relatório Anual de Rodovias Federais Concedidas." (www.antt.gov.br) (Sep. 5, 2012) (in Portuguese).

Baeza, M. A., and Vassallo, J. M. (2010). "Private concession contracts for toll roads in Spain: Analysis and recommendations." Public Money Manage., 30(5), 299-304.

Baeza, M. A., and Vassallo, J. M. (2012). "Traffic uncertainty in toll motorway concessions in Spain: An analysis of the ramp-up period." Proc. ICE Transp., 165(2), 97-105.

Bain, R. (2009). "Error and optimism bias in toll road traffic forecasts." Transportation, $36(5), 469-482$.

Banco Nacional de Desenvolvimento Econômico e Social (BNDES). (2011). "Annual report-Financial statements." (www.bndes.gov.br) (Aug. 13, 2012).

Barbo, A. R., et al. (2010). "A Evolução da Regulaçāo nas Rodovias Federais Concedidas." Revista ANTT, 2(2), 110-123 (in Portuguese).

Bolsa de Valores de São Paulo (BOVESPA). (2012). "Acompanhamento de Leilōes." (www.bmfbovespa.com.br) (Aug. 13, 2012) (in Portuguese).

Brochado, M. R., and Vassallo, J. M. (2012). "Infrastructure finance in developing countries by state and multilateral development banks." Proc., Int. Conf. Industrial Engineering and Operations Management, ABEPRO, Guimarães, Portugal.

Carpintero, S., Vassallo, J., and Soliño, A. (2013). "Dealing with traffic risk in Latin Ametican toll roads." J. Manage. Eng., 10.1061/(ASCE)ME .1943-5479.0000266.

Confederação Nacional do Transporte (CNT). (2012). "Boletim Estatístico Agosto 2012." (www.cnt.org.br) (Sep. 20, 2012) (in Portuguese).

Flyvbjerg, B. (2011). "Case study." Chapter 17, The sage handbook of qualitative research, 4th Ed., Noman $\mathrm{K}$. Denzin and Yvonna $\mathrm{S}$. Lincoln, eds., Sage Publications, Thousand Oaks, CA, 301-316.

Guasch, J. L. (2004). "Granting and renegotiating infrastructure concessions: Doing it right." Development studies sertes, World Bank Institute, Washington, DC.

Hart, O. (2003). "Tncomplete contracts and public ownership: Remarks, and an application to public-private partnerships." Econ. J., 113(486), C69-C76.

Heravi, G., and Hajihosseini, Z. (2012). "Risk allocation in public-private partnership infrastructure projects in developing countries: Case study of the Tehran-Chalus toll road." J. Infrastruct. Syst., 10.1061/(ASCE)IS 1943-555X.0000090, 210-217.

Instituto Brasileiro de Geografia e Estatística (IBGE). (2012). "Sistema Nacional de Índices de Preços ao Consumidor (IBGE/SNIPC)." (www.ibge.gov.br) (Sep. 20, 2012) (in Portuguese).

Instituto de Pesquisa Econômica Aplicada (IPEA). (2011). "Gargalos e Demandas da Infraestrutura Rodoviária e os Investimentos do PAC: Mapeamento Ipea de Obras Rodoviárias." Texto para Discussāo, 1592, Brasilia, Brazil (in Portuguese). 
Instituto de Pesquisa Econômica Aplicada (IPEA). (2012). "Rodovias brasileiras: Investimentos, concessões e tarifas de pedágio." Comunicados do Ipea, 144, Brasilia, Brazil (in Portuguese).

Ke, Y., Wang, S., and Chan, A. (2010). "Risk allocation in public-private partnership infrastructure projects: comparative study." $J$. Infrastruct. Syst, 10.1061/(ASCE)IS.1943-555X.0000030, 343-351.

Lacerda, S. M. (2005). "O financiamento da infra-estrutura rodoviária através de contribuintes e usuários." BNDES Setorial, 21, 141-159 (in Portuguese).

Rosa, M. V. F., Senna, L. A. D. S., and Lindau, L. A. (2010). "Highways concessions: Brazilian view," Proc., World Conf. Transportaiion Research, World Conference on Transport Research Society (WCTRS), Lyon, France, 1-14.
Sánchez Soliño, A., and Gago, P. (2010). "Transaction costs in transport public- private partnerships: Comparing procurement procedures." Transp. Rev, 30(3), 389-406.

Vassallo, J. M. (2006). "Traffic risk mitigation in highway concession projects: The expertence of Chile." J. Transp: Econ. Pol, 40(3), 359-381.

Vassallo, J. M., and Izquierdo, R. (2010). Infraestructura Pública y Participación Privada: conceptos y experiencias en América y España, CAF, Madrid (in Spanish).

Veron, A, and Cellier, J. (2010). "Private participation in the road sector in Brazil: Recent evolution and next steps." Transport Paper, World Bank Group, Washington, DC. 